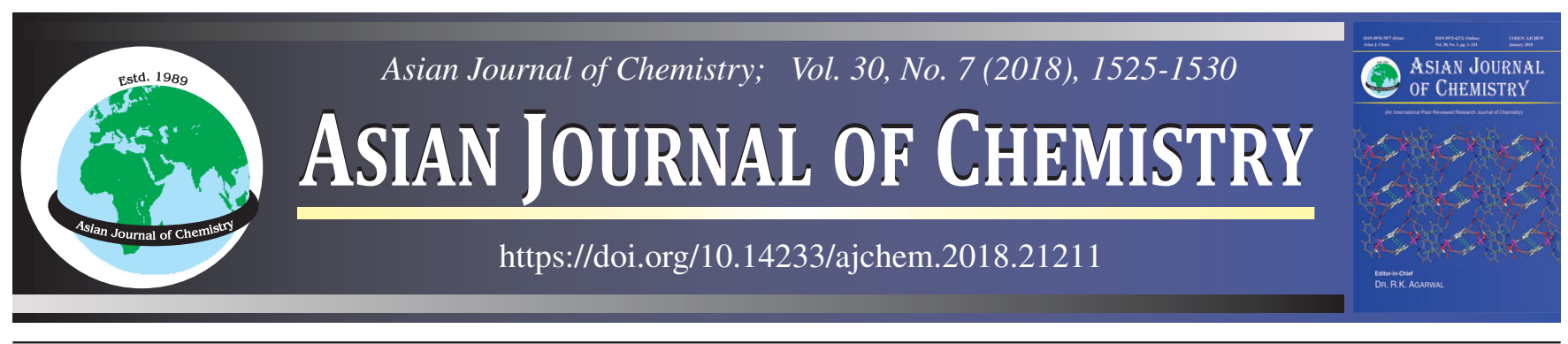

\title{
Evaluation of Corrosivity of Soil Collected from Central Part of Kathmandu Metropolis (Nepal) to Water Supply Metallic Pipes
}

\author{
Kumar Prasad Dahal ${ }^{1, *}$, Raj Kumar Karki ${ }^{2}$ and Jagadeesh Bhattarai ${ }^{1, *}$
}

${ }^{1}$ Central Department of Chemistry, Tribhuvan University, G.P.O. Box 2040, Kathmandu, Nepal

${ }^{2}$ Department of Chemistry, Tri-Chandra Multiple Campus, Kathmandu, Nepal

*Corresponding authors: E-mail: bhattarai_05@yahoo.com; dahalkumar24@yahoo.com

Received: 5 January 2018;

Accepted: 9 February 2018;

Published online: 31 May 2018;

AJC-18925

Corrosive nature of 56 soil samples collected from central parts of Kathmandu metropolis were analyzed using ASTM standards to evaluate their corrosivity towards the water supply underground galvanized-steel and cast iron pipes. Moisture content of 9.7-58.0 \%, 3.0 $8.2 \mathrm{pH}, 1150-27780 \mathrm{Ohm} . \mathrm{cm}$ resistivity, $158-537 \mathrm{mV}$ (saturated hydrogen electrode) oxidation-reduction potential, 13-199 ppm chloride and 30-476 ppm sulfate contents in the collected samples were reported in this study. Results indicated that most of the collected soil samples used in this study is found to be in the range of mildly corrosive to less corrosive nature to the underground galvanized-steel and cast iron pipes. The use of low-cost and easily available materials like gravel and sand around such underground pipes, before burying them in the areas seems to be effective and sufficient to control corrosion of the pipes and to increase their life time in soil of urban areas of Kathmandu metropolis of Nepal.

Keywords: Soil corrosion, Metallic-pipe, Resistivity, Chloride, Sulfate.

\section{INTRODUCTION}

The corrosion of the buried-metallic pipes in soil has long been serious engineering problems [1,2]. A failure of water supply buried-metallic pipes by disturbed soil is high all over the world. In general, it has been assumed that the soil corrosion of the buried-pipes by undisturbed soil is negligible as compared by disturbed soil $[3,4]$ and hence most buried-pipe corrosion study is focused to estimate most effective parameters of the disturbed soil samples for assessing their corrosivity to the pipes. Metallic pipe corrosion in soils is primarily determined by a combined effect of the most effective soil parameters like conductivity or resistivity, $\mathrm{pH}$, ions, moisture, redox potential and so on. Therefore, a relative corrosion risk of the soil to the buried-pipes can estimate by analyzing aforementioned parameters.

Soil $\mathrm{pH}$ is generally one of the most effective soil parameters for showing high corrosivity rate to the buriedmetallic pipes. It is assumed that the $\mathrm{pH}$ ranges from 5 to 8.5 is not usually considered to be a problem for the soil corrosion to the buried-galvanized steel and cast iron pipes [1]. Acidic soil having $\mathrm{pH}$ less than 5 represents serious corrosion risk to the buried-metallic materials and soil $\mathrm{pH}$ around 7 is most desirable to minimize the corrosion damage of buried-metallic pipes. Similarly, there is good correlation between the soil resistivity and corrosivity of buried-metallic materials [1]. The corrosion rate of the buried-metallic materials by soil is generally high, if the soil shows low resistivity. On the other hand, the moisture content in soil is one of the key parameters for showing high corrosivity to the buried-metallic materials. Dry soil shows very high resistivity and hence it was reported less corrosive to the buried-metallic pipes [4-8]. It was reported that the maximum penetration rates and pit depths of the buried-wrought ferrous materials were observed with respect to soil resistivity and $\mathrm{pH}$. The pit depth and the corrosion current were found to be decreased in orders of magnitude with increasing the soil resistivity of $10,000 \mathrm{Ohm} . \mathrm{cm}$ or more as compared with the soil with $1000 \mathrm{Ohm} . \mathrm{cm}$ resistivity or less after exposure for more than 20 years, although such behaviour was not clearly observed for two years or less time exposed in soils [9]. On the other hand, it was reported that the soil resistivity was decreased rapidly with increasing the moisture content until the saturation point was reached $[4,7,8,10]$. It was reported that the highest corrosion rate of steel in soil was corresponded to soil moistures around 60-75 $\%$ saturation $[11,12]$.

The oxidation-reduction potential (ORP) or redox potential of soils is also a significant parameter for the corrosion study of the buried-pipes. A high oxidation-reduction potential value of more than $100 \mathrm{mV}$ (saturated hydrogen electrode) 
generally indicates a high oxygen level in soil. A low oxidationreduction potential value of less than $100 \mathrm{mV}$ (saturated hydrogen electrode) may indicates that soil condition is favourable for anaerobic microbiological activity due to less oxygen available in soil. Iron/steel pipes buried in an anaerobic soil (low oxidation-reduction potential) will not rust, because the soil does not contain any free oxygen, which is needed for the formation of rust on the surface of iron and its alloys. Furthermore, the combination of anaerobic conditions and sulfur in the form of sulfate or sulfide can lead to the soil corrosion. Soil microbes can convert the sulfide that formed from sulfate into sulfuric acid if condition becomes more oxidized [13]. The oxidation-reduction potential value also affects the types of microbiologically induced corrosion (MIC) or bio-corrosion that occurs in soil $[14,15]$.

A chloride and sulfate contents in soil play a major role in the corrosivity of buried-metallic materials [16]. The chloride ions participate for pitting initiation on the surface of stainless steel and hence it tends to increase the soil conductivity. Sulfate is naturally occurring form of sulfur in soils although it is less corrosive towards the underground pipes as compared to the chlorides and it can be readily converted into highly corrosive sulfides by anaerobic sulfate reducing bacteria [17]. It is meaningful to mention here that the soils are generally considered to be mildly corrosive if the sulfate and chloride contents are below $200 \mathrm{ppm}$ and $100 \mathrm{ppm}$, respectively, for the soil with $5.0-8.5 \mathrm{pH}$ and the resistivity greater than 3,000 Ohm.cm [1].

In Nepal, the supply of drinking water from reservoirs to consumers is mostly through the buried-galvanized steel and cast iron pipes. A lot of incidents of losses and contamination in city water occur by corrosion damages of these buried-pipes, although local people are not well aware about the reason for such corrosion. In recent years, there is only few research works are recorded about the corrosion of water supply metallic pipes by soils of Bhaktapur, Lalitpur, Kirtipur and Bharatpur areas of Nepal [18-24]. In this context, main objectives of this work are to establish the corrosive nature of soil samples collected from centre parts of Kathmandu metropolis by estimating six soil parameters of $\mathrm{pH}$, moisture content, resistivity, oxidationreduction potential, chloride and sulfate contents and to correlate these parameters with the standard values established by ASTM and NACE to evaluate the soil corrosivity to the metallic pipes.

\section{EXPERIMENTAL}

Fifty six soil samples were collected from the densely populated areas of Kathmandu metropolis from the depth of one meter from the ground level in the months of September to May. The soil sample was taken in an air tight poly vinyl bag so that the moisture remained same till the time of moisture analysis within $12 \mathrm{~h}$ in the laboratory.

The $\mathrm{pH}$ of 1:2 soil-water extract of each soil samples was determined using a digital $\mathrm{pH}$ meter in accordance with the ASTM G51-95 (2012) standards [25]. Soil moisture content was determined using weight loss method in accordance with the ASTM D4959-07 standards [26]. The soil resistivity was estimated at ambient temperature of $25 \pm 1{ }^{\circ} \mathrm{C}$ in the laboratory using the square soil box method. The conductivity measurement was carried out to determine the electrical conductivity in accordance with the ASTM G187-05 standards [27] and the soil resistivity was calculated from the conductivity value.

The oxidation-reduction potential (ORP) of the soil samples was measured with the help of a digital potentiometer in accordance with the ASTM G200-09 standards [28]. Platinum mesh and saturated calomel electrode (SCE) were used as working and reference electrode, respectively. The recorded oxidation-reduction potential values $v s$. saturated calomel electrode was converted to reference value of the saturated hydrogen electrode (SHE) at $\mathrm{pH}$ 7. Argentometric titration was used to determine chloride in the sample using potassium chromate as an indicator and gravimetric method was used to estimate the amount of sulfate content in soil samples.

\section{RESULTS AND DISCUSSION}

Soil moisture: The moisture contents of all soil samples collected from the present sampling sites of Kathmandu city was found in the range of 9.7-58.0\% as shown in Fig. 1. Among 56 soil samples, 17 samples contained less than $20 \%$ and 30 samples contained $20-40 \%$ moisture content, while remaining 9 soil samples contained more than 40-60\% moisture content. The results revealed that all the soil samples collected from the present sampling sites are assumed to be mildly corrosive $(53.57 \%)$, less corrosive (30.36\%) and moderately corrosive $(16.07 \%)$ based on the soil moisture content.

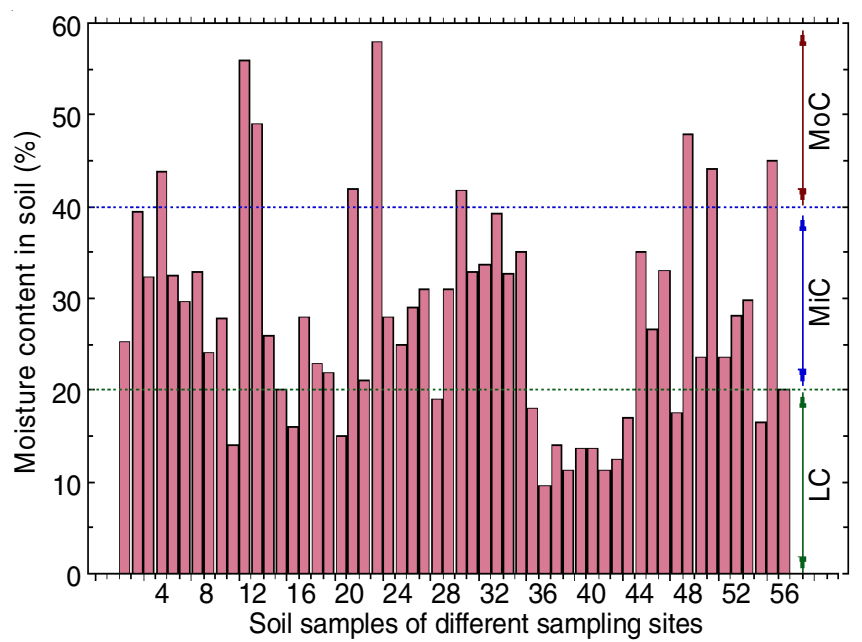

Fig. 1. Moisture content in the soil samples ( $\mathrm{LC}=$ less corrosive; $\mathrm{MiC}=$ mildly corrosive and $\mathrm{MoC}=$ moderately corrosive)

Soil pH: Soil samples collected from the study areas were found to be strongly, slightly acidic, neutral or slightly alkaline in nature having the $\mathrm{pH}$ values ranges from 3.0-8.2 as shown in Fig. 2. The results revealed that 53 soil samples except 3 samples (i.e., sampling site No. 2, 23 and 43) are assumed to be less and mildly corrosive for the underground metallic pipes based on the soil $\mathrm{pH}$ value of 5.0 to 8.5 ranges. Three soil samples collected from sample sites-2, 23 and 43 have the $\mathrm{pH}$ value of 3.0, 3.5 and 4.3 , respectively and hence these soil samples are assumed to be corrosive for the water supply galvanized steel and cast iron pipes based on the soil $\mathrm{pH}$ result. 


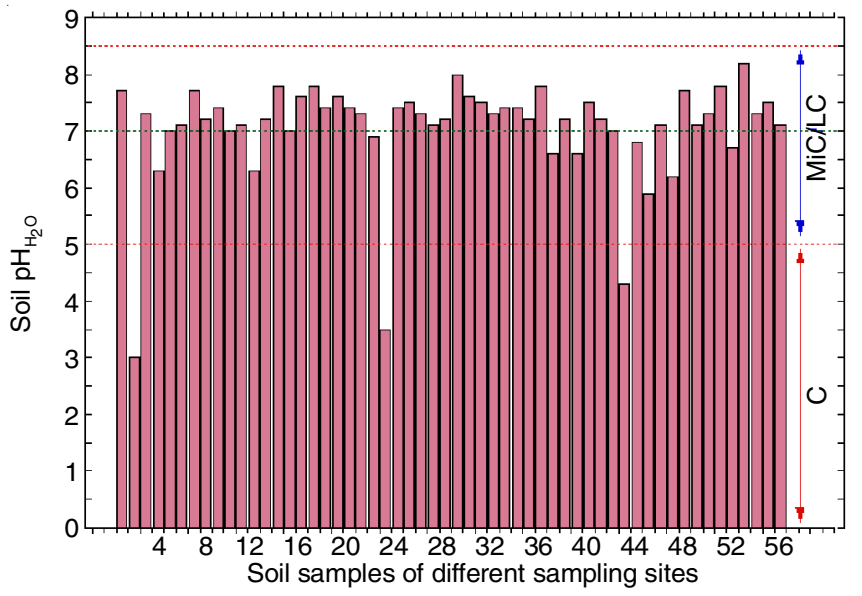

Fig. 2. $\mathrm{pH}$ of the soil samples $(\mathrm{LC}=$ less corrosive; $\mathrm{MiC}=$ mildly corrosive and $\mathrm{C}=$ corrosive)

Soil resistivity: The resistivity of all soil samples analyzed in this study was found in the range of 1150-27780 Ohm.cm (Fig. 3). Among these 56 soil samples, 29 soil samples have the soil resistivity between 5000 and $20000 \mathrm{Ohm} . \mathrm{cm}$, while 25 soil samples have less than $5000 \mathrm{Ohm} . \mathrm{cm}$ resistivity as shown in Fig. 3. On the other hand, 2 soil samples (i.e., sampling site No. 36 and 37) are considered to be less corrosive, because they have the resistivity more than $20000 \mathrm{Ohm} . \mathrm{cm}$. These results revealed that about $52 \%$ of the soil samples collected from the central parts of Kathmandu metropolis are considered to be mildly and moderately corrosive, while about $44 \%$ of the soil samples are considered to be corrosive to the buried-metallic pipes based on the soil resistivity value according to the ASTM classifications as summarized in Table-1 $[29,30]$.

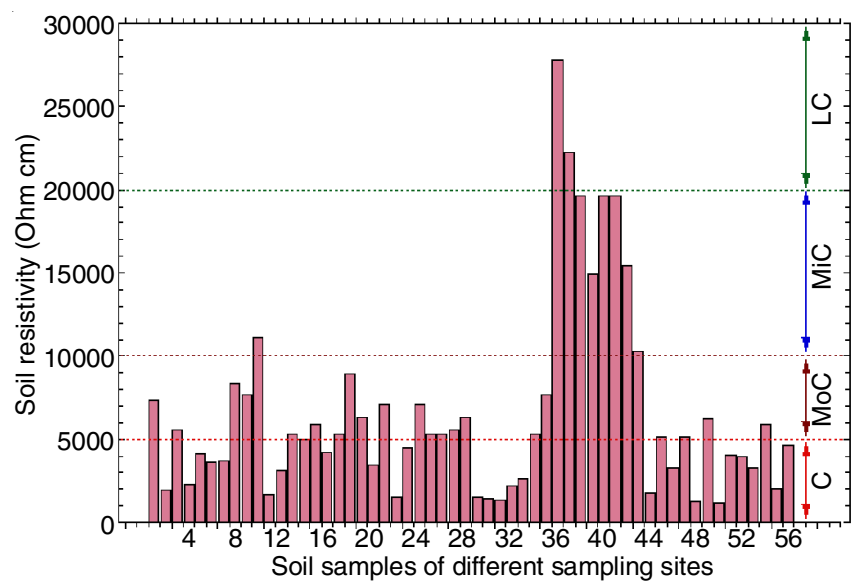

Fig. 3. Resistivity of the soil samples ( $\mathrm{LC}=$ less corrosive; $\mathrm{MiC}=$ mildly corrosive; $\mathrm{MoC}=$ moderately corrosive and $\mathrm{C}=$ corrosive)

\section{TABLE-1}

RATING OF SOIL CORROSIVITY TOWARDS THE BURIED-

METALLIC PIPES BASED ON THE SOIL RESISTIVITY, CHLORIDE AND SULFATE CONTENTS IN SOIL [Ref. 29,30]

\begin{tabular}{cl}
\hline \multicolumn{1}{c}{ Soil parameter } & \multicolumn{1}{c}{ Soil corrosivity } \\
\hline Soil resistivity $($ Ohm.cm) & Less corrosive (LC) \\
$>20,000$ & Mildly corrosive (MiC) \\
$10,000-20,000$ & Moderately corrosive (MoC) \\
$5,000-10,000$ & Corrosive (C) \\
$<5,000$ & Mildly corrosive $(\mathrm{MiC})$ \\
Chloride content $(\mathrm{ppm}):<100$ & Mildly corrosive $(\mathrm{MiC})$ \\
Sulfate content $(\mathrm{ppm}):<200$ &
\end{tabular}

Oxidation-reduction potential of soil: It was found that the oxidation-reduction potential of all soil samples analyzed in this study was found in the range of +158 to $+537 \mathrm{mV} v s$. saturated hydrogen electrode as shown in Fig. 4. Among these 56 soil samples, 50 samples have oxidation-reduction potential value in the range of +200 to $+400 \mathrm{mV} v s$. saturated hydrogen electrode and they are considered to be mildly corrosive towards the galvanized-steel and cast iron pipes. Three samples are considered to be corrosive in nature having the oxidationreduction potential $<+200 \mathrm{mV} v s$. saturated hydrogen electrode. These assessment of the corrosiveness of soil are drawn on the basis of the standard methods $[31,32]$ as given in Table2.

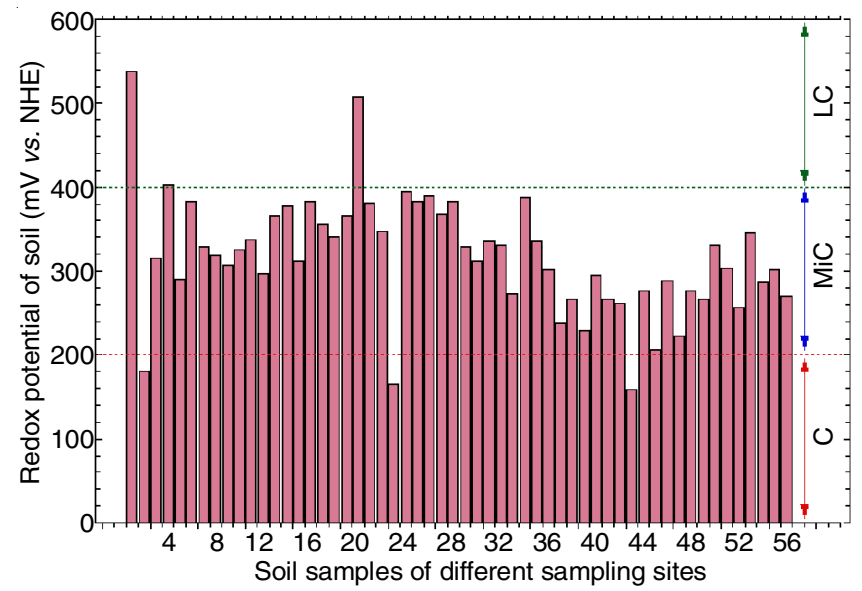

Fig. 4. Oxidation-reduction potential of the soil samples ( $\mathrm{LC}=$ less corrosive $; \mathrm{MiC}=$ mildly corrosive and $\mathrm{C}=$ corrosive)

\begin{tabular}{|c|c|}
\hline \multicolumn{2}{|c|}{$\begin{array}{c}\text { TABLE-2 } \\
\text { RATING OF SOIL CORROSIVITY TOWARDS THE } \\
\text { BURIED-METALLIC PIPES BASED ON THE OXIDATION- } \\
\text { REDUCTION PPOTENTIAL OF SOIL [Ref. 31,32] }\end{array}$} \\
\hline $\begin{array}{l}\text { Oxidation-reduction potential (mV } \\
\text { vs. saturated hydrogen electrode) }\end{array}$ & Soil corrosivity \\
\hline$>400$ & Less corrosive (LC) \\
\hline $201-400$ & Mildly corrosive (MiC) \\
\hline $100-200$ & Moderately corrosive (MoC) \\
\hline$<100$ & Severely corrosive $(\mathrm{C})$ \\
\hline
\end{tabular}

Chloride content in soil: The chloride content in all soil samples was found in the range of 13-199 ppm as shown in Fig. 5. Among these 56 soil samples analyzed in this study, 23 samples have less than $50 \mathrm{ppm}$, while 21 samples have in the range of 50-100 ppm and remaining 12 samples have 100$200 \mathrm{ppm}$ of chloride content. These results revealed that about $79 \%$ soil samples are considered to be mildly and less corrosive towards the buried-galvanized and cast iron pipes used in the study areas. Such rating of soil corrosivity to buried-galvanized steel and cast iron is based on the ASTM classifications [29,30].

Sulfate content in soil: It is reported that soils containing less than $200 \mathrm{ppm}$ of sulphate was considered as mildly corrosive [29,30]. In present study, $54 \%$ of the analyzed soil samples (i.e., 30 samples) are considered to be mildly corrosive, because they contained less than $200 \mathrm{ppm}$ sulfate. Remaining $36 \%$ soil samples (i.e., 20 samples) except 3 samples (i.e., sampling site No. 11, 20 and 23) contained the sulfate in the range of 200-400 ppm (Fig. 6) are considered to be moderately 


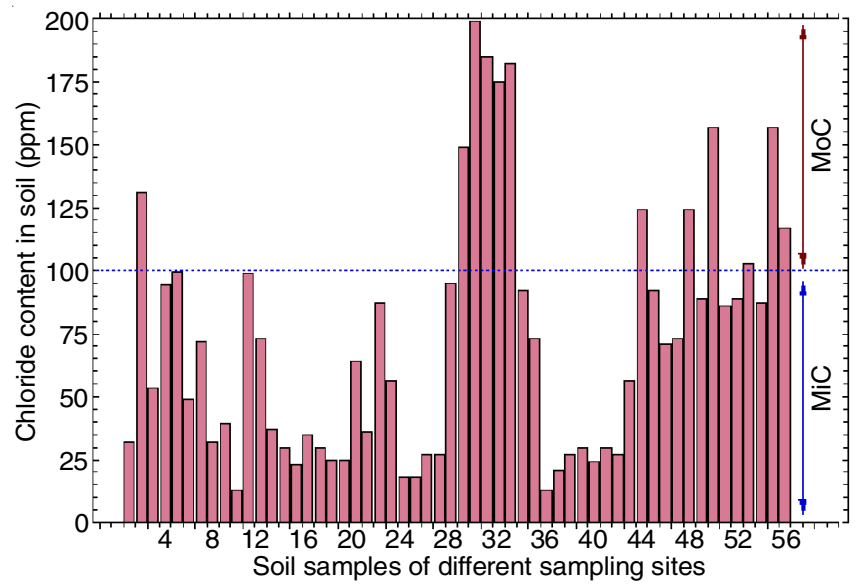

Fig. 5. Chloride content in the soil samples $(\mathrm{MiC}=$ mildly corrosive and $\mathrm{MoC}=$ moderately corrosive $)$

corrosive. Consequently, most of the soil samples are considered to be mildly and moderately corrosive for the buriedmetallic pipes based on the sulfate content in soil samples used in this study.
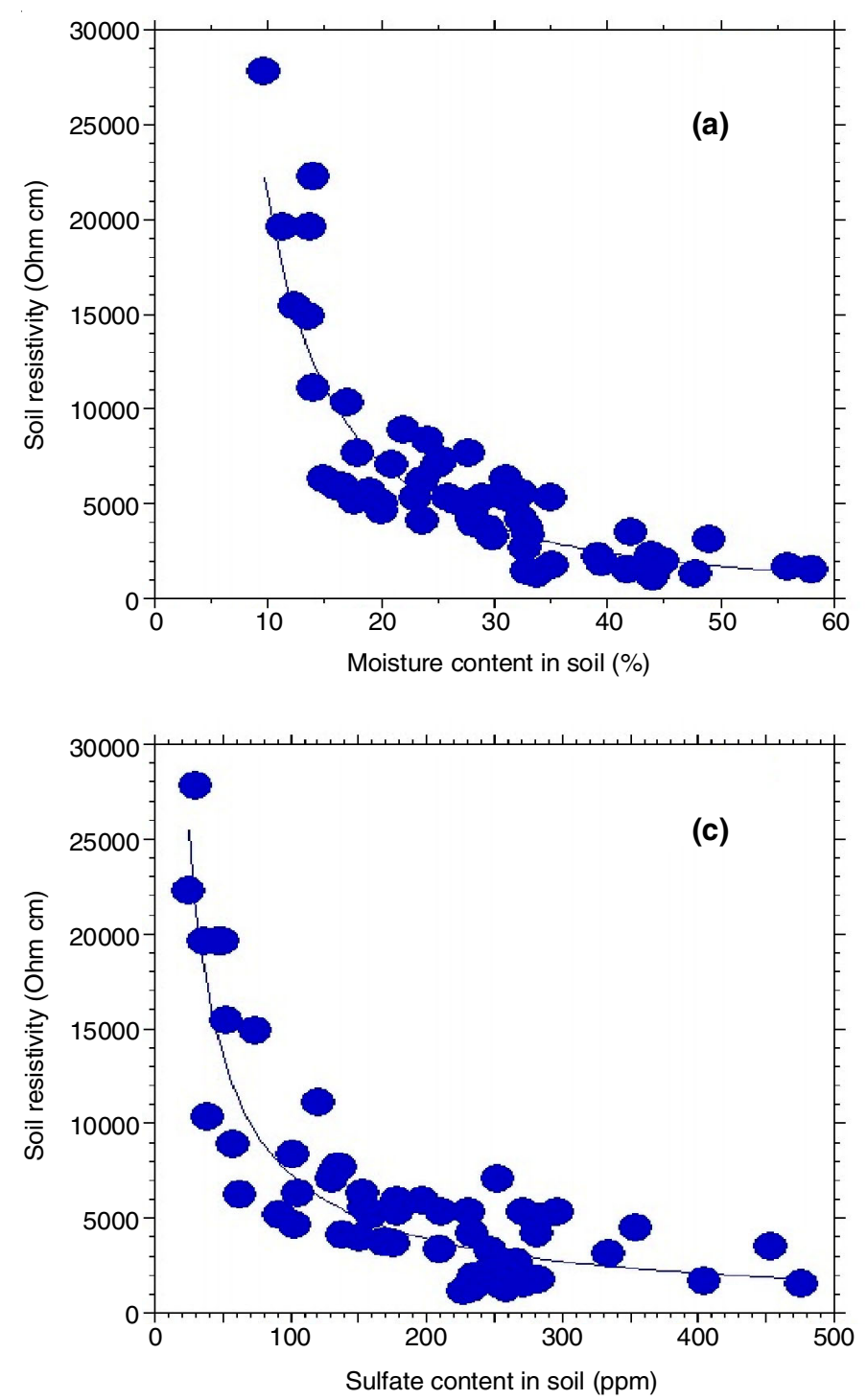

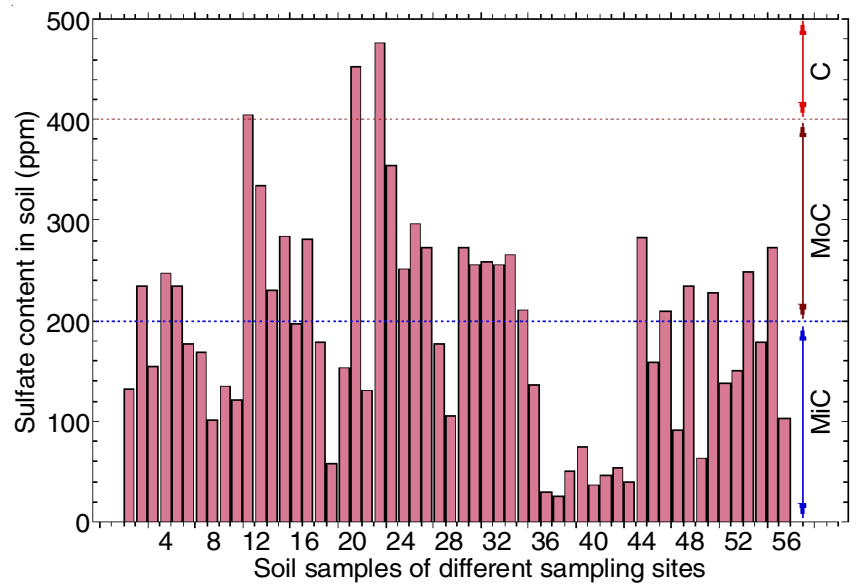

Fig. 6. Sulfate content in the soil samples $(\mathrm{MiC}=$ mildly corrosive; $\mathrm{MoC}=$ moderately corrosive and $\mathrm{C}=$ corrosive)

Correlation between soil resistivity with moisture, chloride and sulfate: The effects of moisture content, chloride and sulfate ions in the soil resistivity were analyzed. A clear correlation between the soil resistivity with moisture, chloride
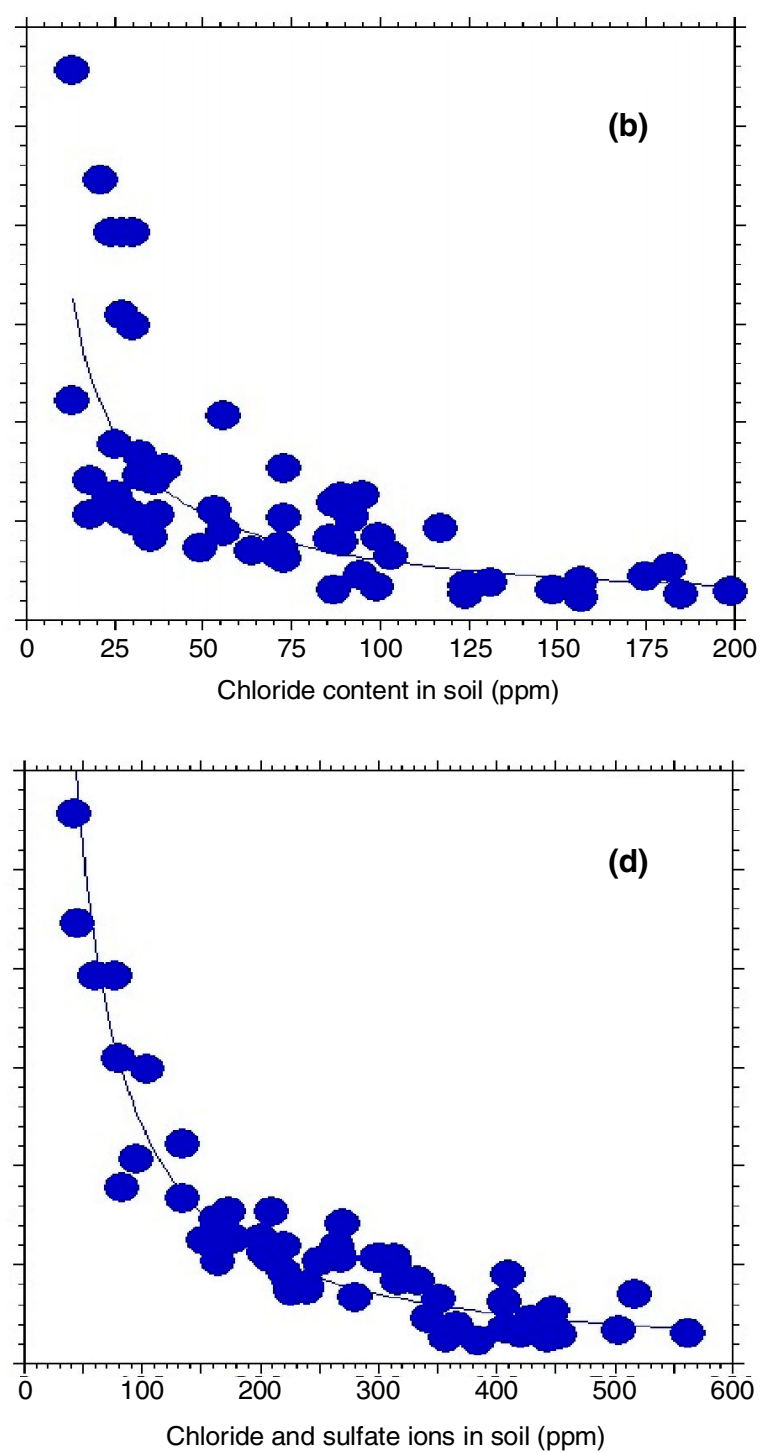

Fig. 7. Changes in the soil resistivity as a function of (a) moisture, (b) chloride, (c) sulfate and sum of chloride and sulfate ions (d) in soil samples 
and sulfate contents in soil samples collected from the study area of Kathmandu metropolis is clearly seen from Fig. 7. Fig. 7(a) shows that the soil resistivity is significantly decreased with increasing the moisture content less than $20 \%$, while a slight decrease in soil resistivity with increasing the moisture content of 20 to $40 \%$ is clearly observed. However, it became almost steady state between 40 to $60 \%$ moisture content in soil samples. In fact, the differences in variation rate of the soil resistivity (the slope of the curve) for different moisture content is very high in less than $20 \%$ and is very low between $40-60 \%$.

In general, moisture content in soil has a profound effect on the soil resistivity. Dry or sandy soil has generally high resistivity. The sandy soil that easily drains water away is typically non-corrosive, while clayey soil that hold more amounts of water shows low resistivity and hence more corrosive towards the buried-metallic materials like galvanized steel and cast iron pipes. It was observed a good correlation between the soil corrosivity towards the buried-metallic materials and the nature of decreasing the soil resistivity with increasing the moisture content in it was reported firstly in 1950s [6-9]. Similarly, a good correlation between the soil resistivity with chloride, sulfate as well as the sum of both chloride and sulfate ions is shown in Figs. 7(b), 7(c) and 7(d), respectively. The soil resistivity is significantly increased with decreasing the amount of $100 \mathrm{ppm}$ chloride and $200 \mathrm{ppm}$ sulfate in soil samples, even though the resistivity of the soil samples becomes almost steady state in the range of 100 to $200 \mathrm{ppm}$ chloride and 200 to $500 \mathrm{ppm}$ of sulfate content. These result revealed that moisture, chloride and sulfate contents in soil contributed to decrease the soil resistivity or to increase the soil corrosivity to the buried-galvanized steel and cast iron pipes in the study areas of Kathmandu.

\section{Conclusion}

The corrosive nature of the 56 soil samples collected from central parts Kathmandu metropolis of Nepal to the buriedmetallic pipes like galvanized-steel and cast iron pipes was studied and the following conclusions are drawn on the basis of the above results and discussion.

- Eighty four percent of the soil samples contained less than $40 \%$ moisture, which is assumed to be mildly corrosive and less corrosive nature to the buried-pipes.

- Almost all soils except 5 samples have $\mathrm{pH}$ within the limits of 6.0-8.0 for showing mildly corrosive and less corrosive to the buried-pipes.

- A high soil resistivity of 5,000 Ohm.cm or more was found for 31 soil samples supports the moderately corrosive to less corrosive nature of soils to the buried-pipes on the basis of the soil resistivity.

- Most of the soil samples except 3 have the oxidationreduction potential of above $+200 \mathrm{mV}$ (saturated hydrogen electrode), which shows mildly corrosive and less corrosive nature to the buried-galva-nized steel and cast iron pipes.

- More than $50 \%$ of the analyzed soil samples contained $<100$ ppm chloride, $<200$ ppm sulphate and $>5,000$ Ohm.cm soil resistivity and hence they are considered to be mildly corrosive and less corrosive nature to the buried-galvanized steel and cast iron pipes.
- The soil resistivity was generally decreased with increasing the moisture, chloride and sulfate contents and a good correlation between the soil resistivity with these three parameters is clearly observed.

It can be concluded that the results presented in this study can enable more accurate prediction of failures of such buriedmetallic pipes used in Kathmandu valley to supply drinking water from reservoir to the consumers.

\section{ACKNOWLEDGEMENTS}

One of the authors (KPD) would like to acknowledge to Nepal Academy of Science and Technology (NAST), Lalitpur, Nepal for providing the NAST Ph.D. scholarship to support this research work.

\section{REFERENCES}

1. R.W. Revie and H.H. Uhlig, Corrosion and Corrosion Control: An Introduction to Corrosion Science and Engineering, John Wiley \& Sons Inc., New Jersey, edn 4, pp. 490 (2008).

2. J. Bhattarai, Frontiers of Corrosion Science, Kshitiz Publication, Kathmandu, Nepal, edn 1, p. 304 (2010).

3. M. Norin and T.-G. Vinka, Mater. Corros., 54, 641 (2003); https://doi.org/10.1002/maco.200303680.

4. I.S. Cole and D. Marney, Corros. Sci., 56, 5 (2012); https://doi.org/10.1016/j.corsci.2011.12.001.

5. K.H. Logan, Underground Corrosion, In: National Bureau of Standards Circular 450, the United States Department of Commerce, Government printing Office, Washington DC (1945).

6. I.A. Denison and M. Romanoff, J. Res. Natl. Bur. Stand., 49, 299 (1952); https://doi.org/10.6028/jres.049.031.

7. I.A. Denison and M. Romanoff, J. Res. Natl. Bur. Stand., 49, 315 (1952); https://doi.org/10.6028/jres.049.032.

8. M. Romanoff, Underground Corrosion, In: National Bureau of Standards Circular 579, the United States Department of Commerce, Government Printing Office, Washington DC (1957).

9. W.J. Schwerdtfeger, J. Res. Natl. Bur. Std.-C. Eng. Instr., 69C, 71 (1965); https://doi.org/10.6028/jres.069C.012.

10. A. Benmoussa, H. Hadjel and M. Traisnel, Mater. Corros., 57, 771 (2006); https://doi.org/10.1002/maco.200503964

11. R. Akkouche, C. R'emazeilles, M. Jeannin, M. Barbalat, R. Sabot and Ph. Refait, Electrochim. Acta, 213, 698 (2016); https://doi.org/10.1016/j.electacta.2016.07.163.

12. R. Akkouche, C. R'emazeilles, M. Barbalat, R. Sabot, M. Jeannin and Ph. Refait, J. Electrochem. Soc., 164, C626 (2017); https://doi.org/10.1149/2.0531712jes.

13. D. Thierry and W. Sand, ed.: P. Marcus, Microbiologically Influenced Corrosion, In: Corrosion Mechanisms in Theory and Practice, CRC Press, New York, pp. 563 (2002).

14. S.Y. Li, Y.G. Kim, K.S. Jeon, Y.T. Kho and T. Kang, Corrosion, 57, 815 (2001); https://doi.org/10.5006/1.3280616.

15. S. Arzola, J. Mendoza-Flores, R. Duran-Romero and J. Genesca, Corrosion, 62, 433 (2006); https://doi.org/10.5006/1.3278280.

16. T.R. Jack and M.J. Wilmott, ed: R.W. Revie, Corrosion in Soils, In: Uhlig's Corrosion Handbook, The Electrochemical Society Inc. \& Wiley, New Jersey, edn 3, pp. 333-349 (2011).

17. T.R. Jack, Biological Corrosion Failures, In: Failure Analysis and Prevention, ASM Handbook, ASM International, Materials Park, OH, vol. 11, pp. 881-898 (2002).

18. K.P. Dahal and J. Bhattarai, Study on the Soil Corrosivity Towards the Underground Pipes in Sinamangal-Baneshwor-Maitidevi-Bagbazar Roadway Areas of Kathmandu, Nepal, In: CORCON 2016 Proceedings, Publication of NIGIS/NACE, New Delhi, 2016 September 19-21, Paper No. PP-11, p. 1-8 (2016).

19. J. Bhattarai, D. Paudyal and K.P. Dahal, $17^{\text {th }}$ Asian Pacific Corrosion Control Conference (APCCC17) Proceedings, Mumbai, India, Paper No. 17039, p. 1-12 (2016). 
20. S.K. Regmi, K.P. Dahal and J. Bhattarai, Nepal J. Environ. Sci., 3, 15 (2015).

21. K.P. Dahal, D. KC and J. Bhattarai, BIBECHANA, 11, 94 (2014); https://doi.org/10.3126/bibechana.v11i0.10387.

22. J. Bhattarai, Sci. World, 11, 43 (2013); https://doi.org/10.3126/sw.v11i11.8551.

23. M. Gautam and J. Bhattarai, Nepal J. Sci. Technol., 14, 65 (2013); https://doi.org/10.3126/njst.v14i2.10417.

24. J. Bhattarai, Investigation of soil Parameters for their Corrosivity on Buried Galvanized Steel Pipelines used in Kathmandu Valley, Research Report, Nepal Academy of Science and Technology-NAST, Lalitpur, Nepal, pp. 41 (2013).

25. ASTM G51-95, Standard Test Method for Measuring $\mathrm{pH}$ of Soil for use in Corrosion Testing, In: Annual Book of ASTM Standards, American Society for Testing and Materials, vol. 03.02 (2012).

26. ASTM D4959-07, Standard Test Method for Determination of Water (Moisture) Content of Soil by Direct Heating, In: Annual Book of ASTM Standards, American Society for Testing and Materials, vol. 03.02 (2007).
27. ASTM G187-05, Standard Test Method for Measurement of Soil Resistivity using Two-Electrode Soil Box Method, In: Annual Book of ASTM Standards, American Society for Testing and Materials, vol. 03.02 (2005).

28. ASTM G200-09, Standard Test Method for Measurement of OxidationReduction Potential (Orp) of Soil, In: Annual Book of ASTM Standards, American Society for Testing and Materials, vol. 03.02 (2009).

29. E. Escalante, eds.: V. Chaker and J.D. Palmer, Effect of Soil Characteristics on Corrosion, In: Concepts of Underground Corrosion, American Society for Testing and Materials, Philadelphia, p. 81-94 (1989).

30. J.D. Palmer, eds.: V. Chaker and J.D. Palmer, Environmental Characteristics Controlling the Soil Corrosion of Ferrous Piping, In: Concepts of Underground Corrosion, American Society for Testing and Materials, Philadelphia, p. 5-17 (1989).

31. D.A. Jones, Principles and Prevention of Corrosion, Prentice Hall, edn. 2 (1996)

32. R.L. Starkey and K.M. Wight, Corrosion, 3, 227 (1947); https://doi.org/10.5006/0010-9312-3.5.227. 